EGG-WID--10354

DE93 001939

\title{
Fugitive Dust Control Experiments Using Soil Fixatives on Vehicle Traffic Surfaces
}

M. R. Winberg

V. E. Wixom

Published August 1992

Idaho National Engineering Laboratory

EG\&G Idaho, Inc.

Idaho Falls, Idaho 83415

Prepared for the

U.S. Department of Energy

Office of Environmental Restoration and Waste Management

Under DOE Idaho Field Offlce

Contract DE-AC07-76ID01570 
Fugitive Dust Control Experiments Using Soil Fixatives on Vehicle Traffic Surfaces EGG-WTD-10354

Reviewed by:

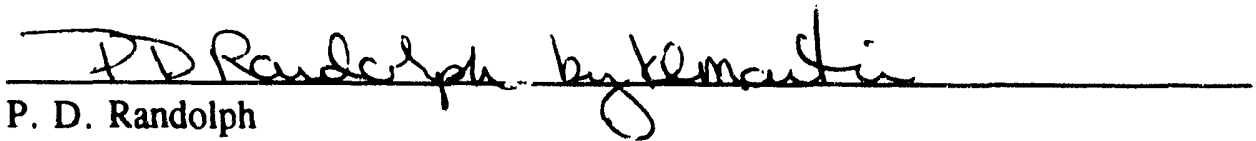

Nuclear Sciences
$8 / 28 / 92$

Date

Approved by:

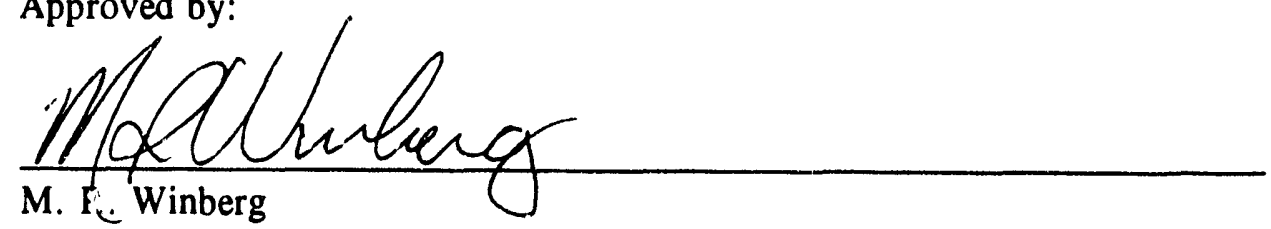

M. F. Weinberg $\frac{8 / 28 / 92}{\text { Date }}$ Project Scientist
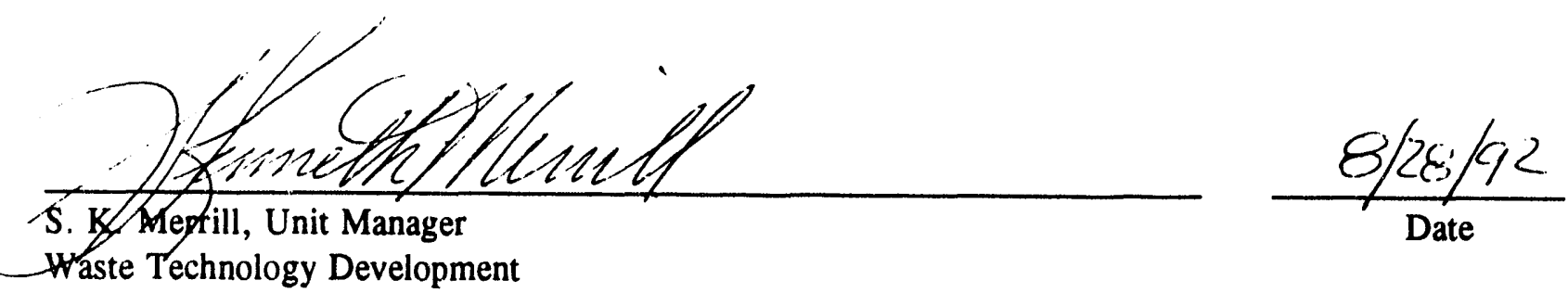

K. L. Martin, Ont Manager Nuclear Sci ices

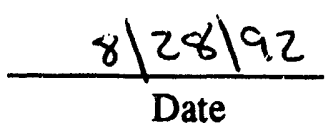




\begin{abstract}
This report presents the results of engineering scale dust control experiments using soil fixative for contamination control during handling of transuranic waste. These experiments focused on controlling dust during retrieval operations of buried waste where waste and soil are intimately mixed. Sources of dust generation during retrieval operations include digging, dumping, and vehicle traffic. Because contaminants are expected to attach to soil particles and move with the generated dust, control of the dust spread may be the key to contamination control. Dust control techniques examined in these experiments include the use of soil fixatives to control generation of fugitive dusts during vehicle traffic operations. Previous experiments conducted in FY 1990 included testing of the soil fixative, ENTAC. These experiments showed that ENTAC was effective in controlling dust generation but had several undesirable properties such as slow cure times and clogged the pumps and application nozzles. Therefore, other products would have to be evaluated to find a suitable candidate. As a result, two soil fixatives were tested in these present experiments, COHEREX-PM, an asphalt emulsion product manufactured by Witco Corporation and FLAMBINDER, a calcium lignosulfonate product manufactured by Flambeau Corporation. The results of the experiments include product performance and recommended application methods for application in a field deployable contamination control unit to be built in FY 1993.
\end{abstract}




\section{EXECUTIVE SUMMARY}

A series of engineering scale dust-control experiments were performed to examine the effectiveness of soil fixatives for controlling dust spread during vehicle movement operations. This is a common operation expected during retrieval of buried transuranic (TRU) wastes. Because contaminants are expected to attach to soil particles, controlling the spread of generated dust is the key to controlling the spread of TRU materials. Although the engineering scale experiments were modeled to represent retrieval operations, the results are applicable to any operation where TRU materials may be prone to migrate with dust. Previous studies conducted in FY 1990 tested a product called ENTAC as a oil fixative. Entac is a organic resin derived from treesap. It is a byproduct of the lumber milling industry. Experiments conducted with ENTAC found that it was effective in controlling fugitive dust generation during simulated vehicle traffic operations. However, ENTAC had several undesirable properties such as clogging of application equipment and long cure times. It was determined that other products would have to be investigated. This report presents the results of the experiments conducted to determine the effectiveness of other soil fixatives to control fugitive dust generation of vehicle traffic surfaces. The product of choice will be used in a Field Deployable Contamination Control Unit (FDCCU) to be built in FY 1993.

Two soil fixatives were selected for testing to determine their effectiveness in controlling fugitive dust generation on vehicle traffic surfaces. The two products tested were COHEREX-PM manufactured by Witco Corporation and FLAMBINDER manufactured by Flambeau Paper Corporation. The products were tested using the same methods used to test another soil fixative, ENTAC manufacture by Entac Corporation, which was tested during FY 1990. The products were tested by first applying the product to a test area of soil according to the manufacturer's specifications. The test area was driven over by a lawn tractor to simulate vehicle traffic approximately 30 vehicle passes. The product was then reapplied over the original coat and the process repeated until a total of 90 vehicle passes were made over three applications of the product. During this process, air particulate samples were collected to measure the dust concentration in the test area during the driving operations. The results of these tests were compared to tests conducted with no product applied to the test bed to establish a control efficiency $\left(\mathrm{C}_{\mathrm{eff}}\right)$ that is the percentage of dust removed and control factor (CF), which is the ratio of the unfixed to the fixed dust concentrations for each product as a function of the number of vehicle passes.

The results of these test showed that the product FLAMBINDER had an average $\mathrm{C}_{\text {eff }}$ of 84.3 $+/-7.4 \%$ and a average $C F$ of $6.6+/-4.4$ over 90 vehicle passes. COHEREX-PM had a average $\mathrm{C}_{\text {.eff }}$ of $89.1+/ 5.9 \%$ and a average $\mathrm{CF}$ of $10.4+/-9.6$. The results of the tests indicated that there is little difference in either product for the factors of curing time, application methods, or application costs. However, there may be a potential environmental conflict with COHEREX-PM in being an environmentally acceptable product because it is composed of petroleum resins in a water emulsion. FLAMBINDER is a byproduct of the lumber milling industry and is made up of naturally occurring organic resins and should have no potential for environmental conflict. From an applications standpoint both products are suitable for use in the FDCCU. An application system can be procured and built using commercially available, off the shelf equipment that can dispense either product. 
The results of these experiments indicate that either product may be suitable for use as a soil fixative on yehicle traffic surfaces during TRU waste retrieval and handling operations provided that the potential environmental conflicts with COHEREX-PM can be resolved. Either product can be mixed and applied using the system currently planned for the FDCCU. 


\section{ACKNOWLEDGEMENTS}

The author(s) wish to express appreciation to the following individuals for contributions making this experiment possible: U. S. Wallace for providing laboratory technical support in conducting the experiments detailed in this report; P. D. Randolph for technically reviewing this report; and Test Reactor Area equipment operators, carpenters, and laborers for providing skilled help in performing these experiments. 


\section{CONTENTS}

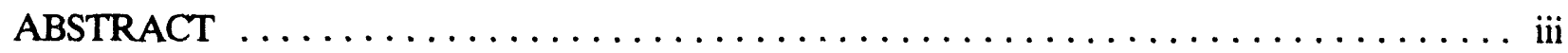

EYECUTTVE SUMMARY $\ldots \ldots \ldots \ldots \ldots \ldots \ldots \ldots \ldots \ldots \ldots \ldots \ldots \ldots \ldots$

ACKNOWLEDGEMENTS $\ldots \ldots \ldots \ldots \ldots \ldots \ldots \ldots \ldots \ldots \ldots \ldots \ldots \ldots$ vii

ACRONYMS $\ldots \ldots \ldots \ldots \ldots \ldots \ldots \ldots \ldots \ldots \ldots \ldots \ldots \ldots \ldots \ldots \ldots \ldots \ldots \ldots \ldots$

1. INTRODUCTION $\ldots \ldots \ldots \ldots \ldots \ldots \ldots \ldots \ldots \ldots \ldots \ldots \ldots \ldots \ldots \ldots$

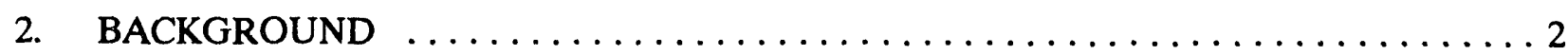

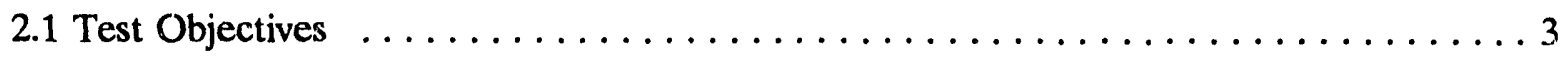

3. TEST METHODS $\ldots \ldots \ldots \ldots \ldots \ldots \ldots \ldots \ldots \ldots \ldots \ldots \ldots \ldots \ldots \ldots$

4. TEST RESULTS $\ldots \ldots \ldots \ldots \ldots \ldots \ldots \ldots \ldots \ldots \ldots \ldots \ldots \ldots \ldots$

5. DISCUSSION AND RECOMMENDATIONS $\ldots \ldots \ldots \ldots \ldots \ldots \ldots \ldots \ldots$

7. REFERENCES $\ldots \ldots \ldots \ldots \ldots \ldots \ldots \ldots \ldots \ldots \ldots \ldots \ldots \ldots \ldots \ldots \ldots$

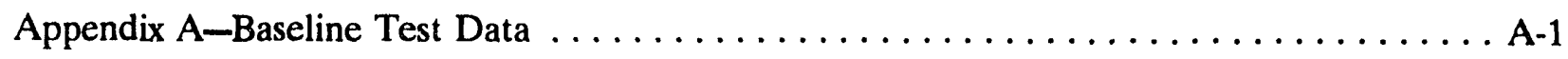

Appendix B-Calculational Mettods $\ldots \ldots \ldots \ldots \ldots \ldots \ldots \ldots \ldots \ldots \ldots \ldots \ldots \ldots$

FIGURES

1. Floor plan of ETRC and containment enclosure $\ldots \ldots \ldots \ldots \ldots \ldots \ldots \ldots$

2 Photograph of containment enclosure $\# 1 \ldots \ldots \ldots \ldots \ldots \ldots \ldots \ldots \ldots$

3. Photograph of containment enclosure $\# 2 \ldots \ldots \ldots \ldots \ldots \ldots \ldots \ldots \ldots$

4. Layout of containment enclosure and sampling locations $\ldots \ldots \ldots \ldots \ldots \ldots$

5. Photograph of spray application system used in testing $\ldots \ldots \ldots \ldots \ldots \ldots$

6. Comparison of soil fixative control efficiencies $\ldots \ldots \ldots \ldots \ldots \ldots \ldots \ldots$ 


\section{TABLES}

1. Product dilution ratios and application rates as tested $\ldots \ldots \ldots \ldots \ldots \ldots \ldots$

2. COHEREX-PM data summary $\ldots \ldots \ldots \ldots \ldots \ldots \ldots \ldots \ldots \ldots \ldots \ldots \ldots \ldots \ldots$

3. FLAMBINDER data summary $\ldots \ldots \ldots \ldots \ldots \ldots \ldots \ldots \ldots \ldots \ldots \ldots \ldots \ldots$ 


\section{ACRONYMS}

$\begin{array}{ll}\mathrm{C}_{\text {eff }} & \text { control efficiency } \\ \text { CF } & \text { Control factor } \\ \text { DOE } & \text { U.S. Department of Energy } \\ \text { DOT } & \text { Department of Transportation } \\ \text { EST } & \text { Engineering scale tests } \\ \text { ETRC } & \text { Engineering Test Reactor Critical Facility } \\ \text { FDCCU } & \text { Field Deployable Contamination Control Unit } \\ \text { INEL } & \text { Idaho National Engineering Laboratory } \\ \text { MSDS } & \text { Material Safety Data Sheets } \\ \text { RWMC } & \text { Radioactive Waste Management Complex } \\ \text { SDA } & \text { Subsurface Disposal Area } \\ \text { TRU } & \text { Transuranic } \\ \text { TSA } & \text { Transuranic Storage Area }\end{array}$




\section{INTRODUCTION}

This report presents the results of engineering scale tests (ESTs) conducted as part of an ongoing research plan to test commercially available soil fixatives for dust control on vehicle traffic surfaces. These dust control techniques may be part of a contamination control system to be used in the retrieval of buried radioactive wastes at the Idaho National Engineering Laboratory (INEL) Radioactive Waste Management Complex (RWMC). Contamination control is an important subsystem of an overall retrieval system. The main contaminates to be controlled are plutonium and americium compounds associated with transuranic (TRU) contaminated wastes.

The experiments conducted during these experiments were designed to test on a large scale the performance of dust suppression agents for application in a field deployable contamination control unit to be constructed during FY 1993. Previous work conducted in FY 1988 through 1991 identified and tested candidate vendor products and application systems. ${ }^{1,2}$ These products were tested as part of the ESTs to determine their overall performance and to recommend application methods. These experiments were conducted using the test plan and EG\&G Idaho, Inc. Science and Technology Standard Practices Manual. ${ }^{3,4}$

This report presents the background information, test objectives, test methods, results, and conclusions for experiments testing two soil fixatives for fugitive dust control on vehicle traffic areas during waste retrieval and handling operations. The results of these experiments will determine a suitable soil fixative for use in a tield deployable contamination control unit. 


\section{BACKGROUND}

The U.S. Department of Energy (DOE) weapons complex has produced waste contaminated with TRU elements, primarily plutonium and americium. Some of this waste was buried in shallow land pits and trenches; however, other wastes are stored aboveground under earthen cover. Examples of these storage practices at the INEL include the Subsurface Disposal Area (SDA), pits and trenches, Pad A at the SDA, and the Transuranic Storage Area (TSA). Retrieving and processing these stored materials for final deposition has the potential for considerable spread of TRU contamination because of the highly mobile nature of the TRU contaminants. High toxicity and low allowable body burden require maximum achievable control of these materials. Compounding the control problem is the potential for plutonium to attach to dust particles and migrate with the fugitive dust generated through retrieving or handling this waste.

During FY 1989, a conceptual design for a system controlling contamination during retrieval at the RWMC was developed. ${ }^{5}$ This system involved (a) maintaining the naturally occurring moisture in the wasie zone, (b) ventilating the retrieval area, and (c) providing rapid detection of contamination to provide trend data for levels of airborne and surface contamination. The purpose of the system was to control dust generation through the use of misting systems during digging and dumping operations, soil fixatives to stabilize and maintain the natural moisture of the digging area, and dust suppression agents to control dust generation at vehicle traffic areas.

During FY 1988 and 1990, literature searches were conducted with candidate vendor products and application systems being identified. Glove box scale tests were performed, resulting in the selection of several vendor products and application systems for potential use in retrieval.

During the FY 1989 testing, it was evident that testing on a larger scale would be necessary to determine the effectiveness of each product for use in retrieval operations. In FY 1990, a soil fixative was tested using the same methods used in this study. The product ENTAC, an organic resin derived from treesap, was tested to determine its ability to control fugitive dust generation from vehicle movement on a soil floor. Tests on ENTAC determined that although ENTAC provided a suitable dust control efficiency of $87 \%$ over 90 vehicle passes, the product had several undesirable properties such as a long indoor cure time, potential clogging of applications systems, and a long time frame to establish an initial base to maintain adequate control.

It was determined that other soil fixatives would have to be investigated to find a suitable vendor product that would meet program requirements. During the literature searches and vendor inquiries, several candidate products were identified and investigated. Two products were identified for testing

1. COHEREX-PM, an asphalt emulsion product manufactured by Witco Corporation

2. FLAMBINDER, a calcium lignosulfonate product manufactured by Flambeau Corporation.

These products were then tested using the manufacturer's recommended application rates and methods and the same experimental methods used to test ENTAC. The results of these tests will be used to select a suitable product to use as a soil fixative in the field deployable contamination control unit to be constructed in FY 1993. 


\subsection{Test Objectives}

The objective of the experiments conducted in this report is to select a suitable soil fixative for use in the field deployable contamination-control unit to he constructed in FY 1992. In addition, the product selected may have application in future retrieval demonstration activities at the INEL's RWMC. The successful candidate product should meet the following requirements:

- Environmentally acceptable for application and use at the INEL

- Easily applied with off the shelf application systems

- Economical to use in large scale waste retrieval an handling activities

- Relatively short cure time ( $<8$ hours) in an indoor containment with no direct sunlight and air movement

- Dust control efficiency of $>85 \%$ on a test area with the product applied when compare to a test area with no product applied. 


\section{TEST METHODS}

All testing was conducted in an enclosure constructed of $2 \times 4$ in. studs and plastic sheets built in Material Test Reactor-654 of the Engineering Test Reactor Critical (ETRC) facility. A diagram of the enclosure with its dimensions is shown in Figure 1 and photographs of the containment enclosure are shown in Figures 2 and 3 . This enclosure has a fan and motor attached to simulate the effects of the laminar ventilation system used to pull the air back away from the test area. Samplers were arranged in the enclosure to collect particulate dusts generated during testing. The particulate samplers were connected to electronic mass flow sensors and valves to measure and regulate each sampler air flow. The electronic r.ass flow sensors are connected to a data-logger that was connected to a PC for data acquisition and storage.

The retrieval concept tested involved using a transporter to transfer a dumpster, which is full of waste material, over a dirt floor to a sorting area. Soil fixatives wouid be used to minimize dust generation and possible contamination spread caused by vehicle movement between the digface and the sorting area. Testing for the dust generation by vehicle movement was conducted by placing a 6-in. deep bed of soil in the containment structure at ETRC. The soil was compacted and raked as level as possible. Eight particulate samplers were placed at locations within the containment building at alternating heights of 5 and $6 \mathrm{ft}$, as shown in Figure 4. A John Deere lawn tractor was used to simulate vehicle traffic movement along the soil test bed. The containment ventilation system was turned on to achieve a 40 linear $\mathrm{ft} / \mathrm{min}$. air flow across the test area. The sampler pumps were iurned on, and the equipment operator began to drive the tractor back and forth across the test area. Vehicle movement was sustained for 5 minutes during which the equipment operator made an average of 30 passes over the test area. The air samplers were then turned off, and the filters were collected and analyzed. Sample resuits were recorded in the project logbook and database for final analysis. A series of three tests on a dry ( $<4 \%$ moisture content) soil bed without product applied were conducted to establish an average air concentration in the containment structure.

Both of the products tested are shipped from the manufacturer in concentrated form and diluted with water before application. Both products use a spray type application from a premixed tank. A garden type sprayer with a motor and sprayer was used to apply both products and is shown in Figure 5. The vendor application rates and dilution ratios for each product are shown in Table 1.

Product was applied to the test bed using the initial application parameters and allowed to cure. The tractor was then driven over the test bed for 30 passes as done in the test with no product applied and particulate samples were collected. The product was then applied using the follow up application parameters shown in Table 1. The bed was driven on again, and samples collected. This method was repeated until 90 vehicle passes were completed. 


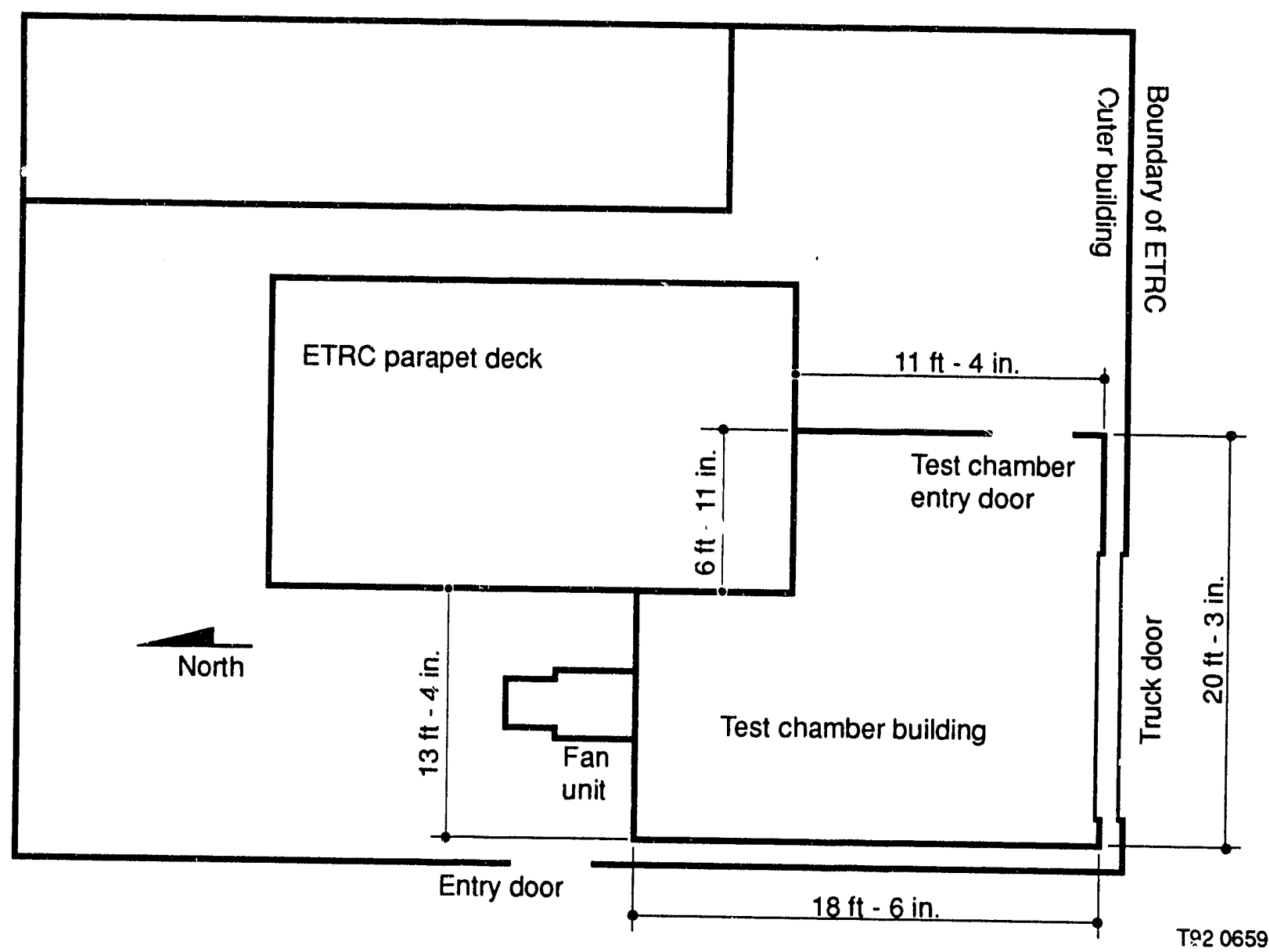

Figure 1. Floor plan of ETRC and containment enclosure. 


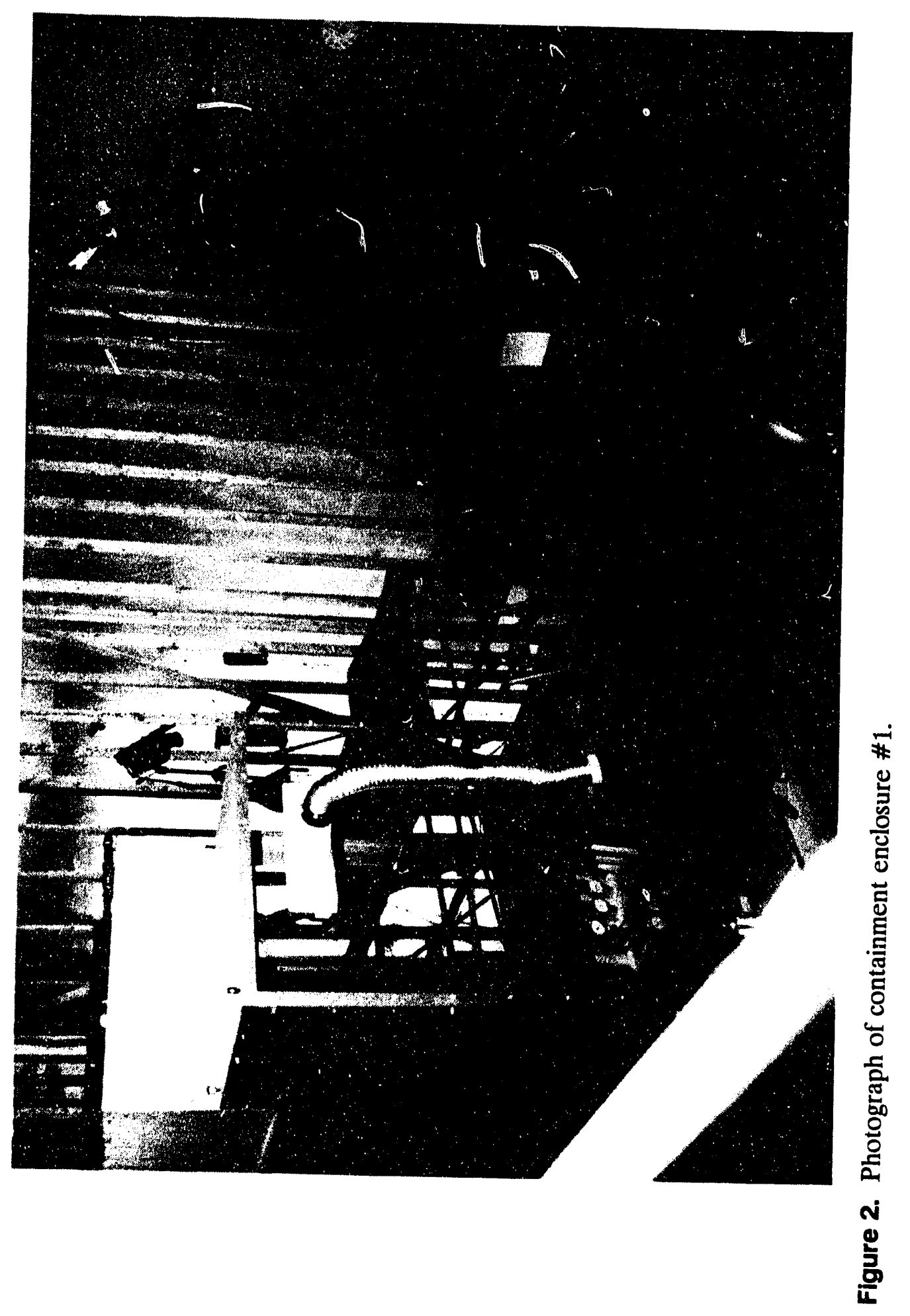




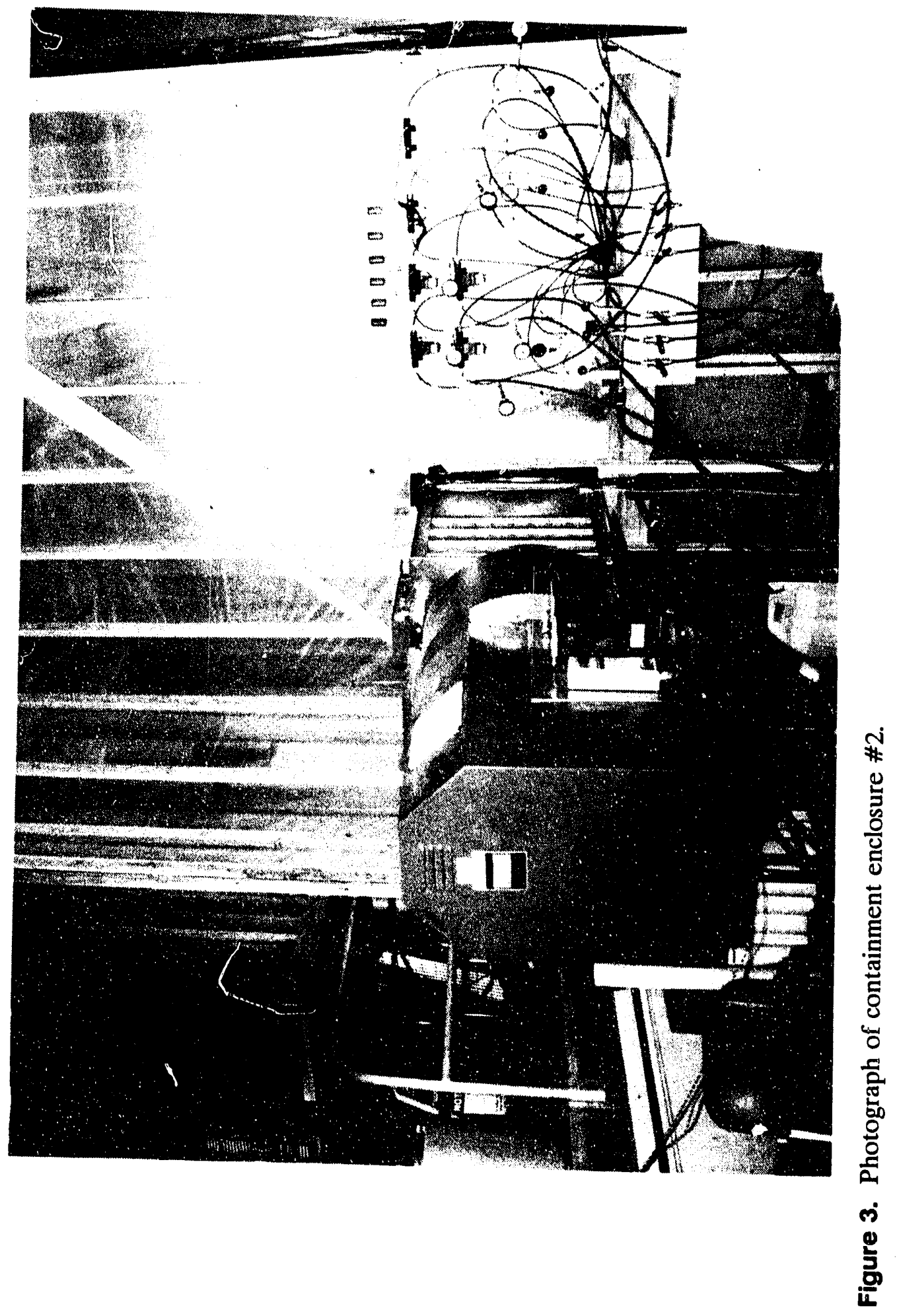




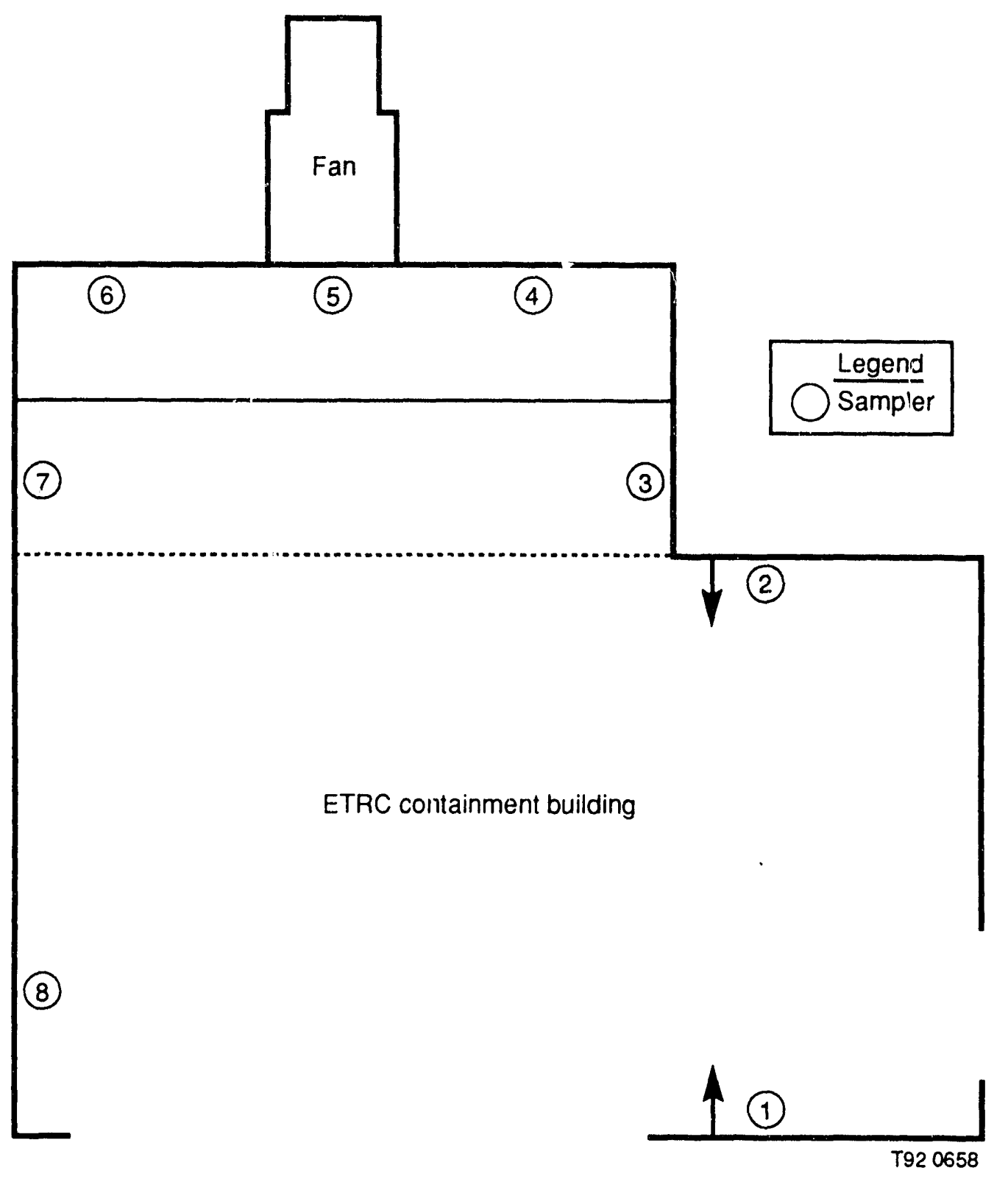

Figure 4. Layout of containment enclosure and sampling locations. 


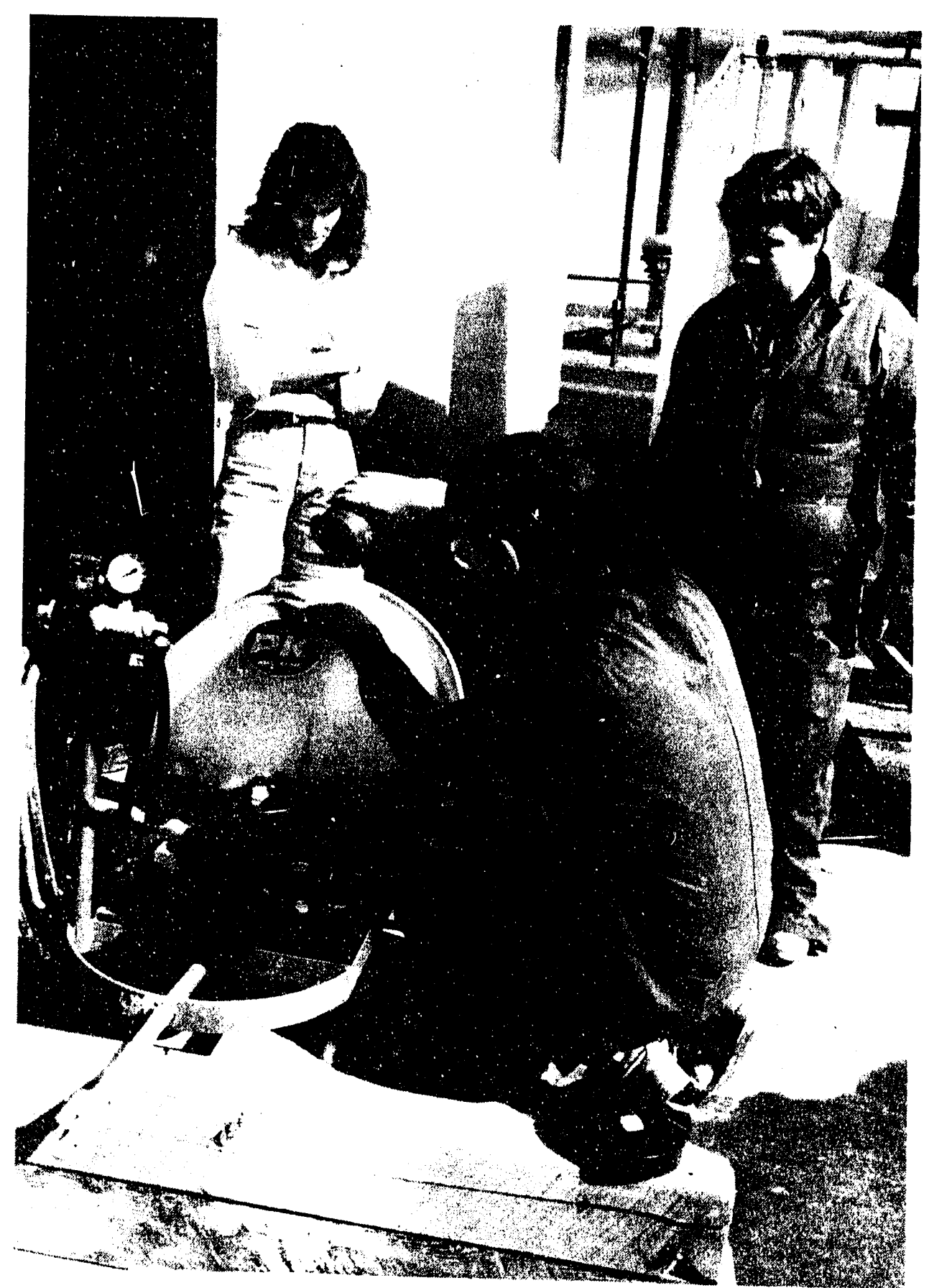

Figure 5. Photograph of spray application system used in testing. 
Table 1. Product dilution ratios and application rates as tested.

\begin{tabular}{lcc}
\hline \multicolumn{1}{c}{ Parameter } & COHEREX-PM & FLAMBINDER \\
\hline $\begin{array}{l}\text { Initial dilution ratio } \\
\text { (water/product) }\end{array}$ & $3 / 1$ & $3 / 1$ \\
$\begin{array}{l}\text { Application rate } \\
\left(\text { gal/yr }{ }^{2}\right)\end{array}$ & 1 & 1 \\
$\begin{array}{l}\text { Follow-up dilution } \\
\text { ratio (water/product) } \\
\text { Application rate } \\
\left(\text { gal/yd }^{2}\right)\end{array}$ & $5 / 1$ & $5 / 1$ \\
\hline
\end{tabular}




\section{TEST RESULTS}

The data were analyzed to determine an average dust concentration for all sample locations for each sequence of 30 vehicle passes. These averages were calculated for the baseline tests with no product applied and with each product applied. These air concentrations were used to calculate a control efficiency $\left(\mathrm{C}_{\text {eff }}\right)$, which is the percentage of dust removed, and control factor $(\mathrm{CF})$, which is the ratio of the unfixed to the fixed dust concentrations, for each product. Methods used to calculate these analyses and found in Appendix A of this report.

The results of the vehicle traffic tests are shown in Tables 2 and 3. The top half of the tables show the average initial dust concentration with no product applied for each sample location. The average ior these sample locations is based upon a repetition of three tests. The next colunins show the dust concentrations for each sample location as a function of the number of vehicle passes based on a single tes: The final column shows the average and standard deviation for each sample location for all tests with product applied for a total 0-90 vehicle passes. The lower half of the table shows the Ceff and CF for the product as a function of the number of vehicle passes. The last columns show the Ceff and CF for 0-90 vehicle passes based on all the tests conducted. This number is used as the overall Ceff and CF for the product at each location. The bottom of each column shows the average Ceff and CF and average standard deviation for all samples collected for each test. The Ceff plotted as a function of number of vehicle passes is shown in Figure 6. The Ceff for both products show that the products performed relatively equally between the baseciat and followup applications. The experimenters noted that COHEREX-PM tended to perform slight ly better although statistically there is no difference in the Ceff of these products. Observations of the penetration depth of each product showed COHEREX-PM penetrated to average depth of $3 / 4$ in. with a maximum penetration of 1-1/4 in. and FLAMBINDER had a arerage penetration depth of $1 \mathrm{in}$. and a maximum penetration depth of 4 in. (Note: this area was a depression in the soil floor where the product puddled before drying) outside of this area the maximum depth was 2 in. 


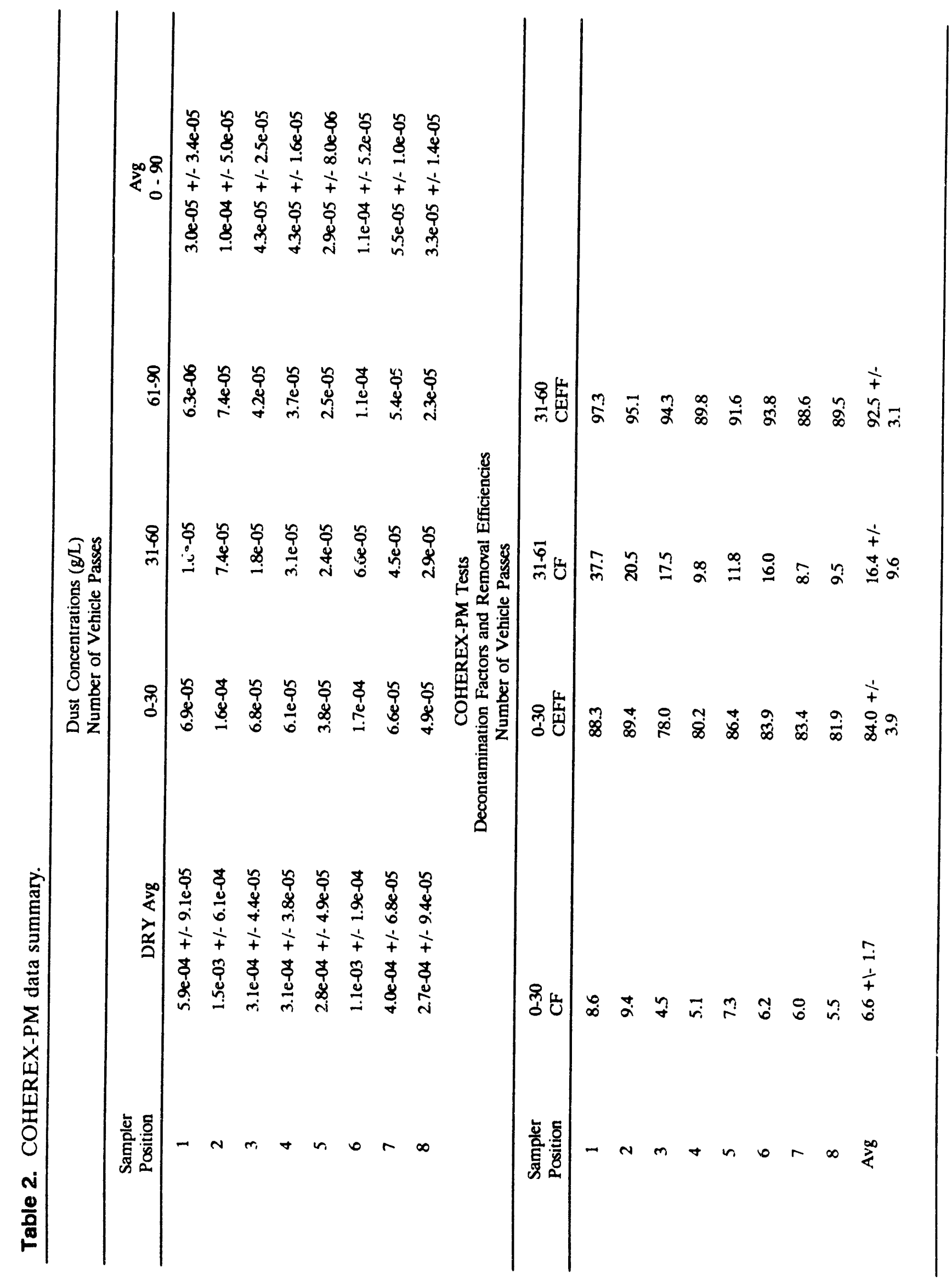




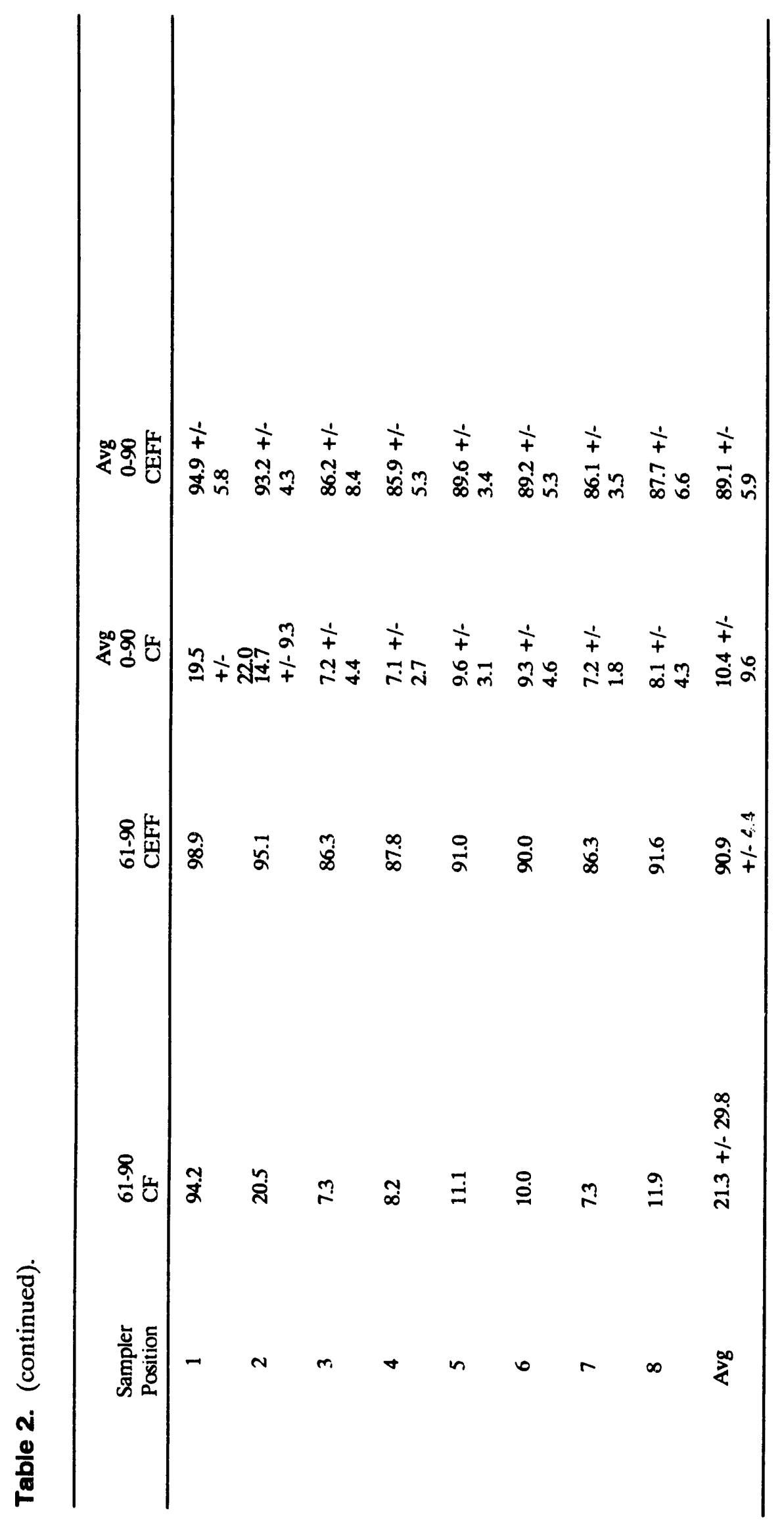




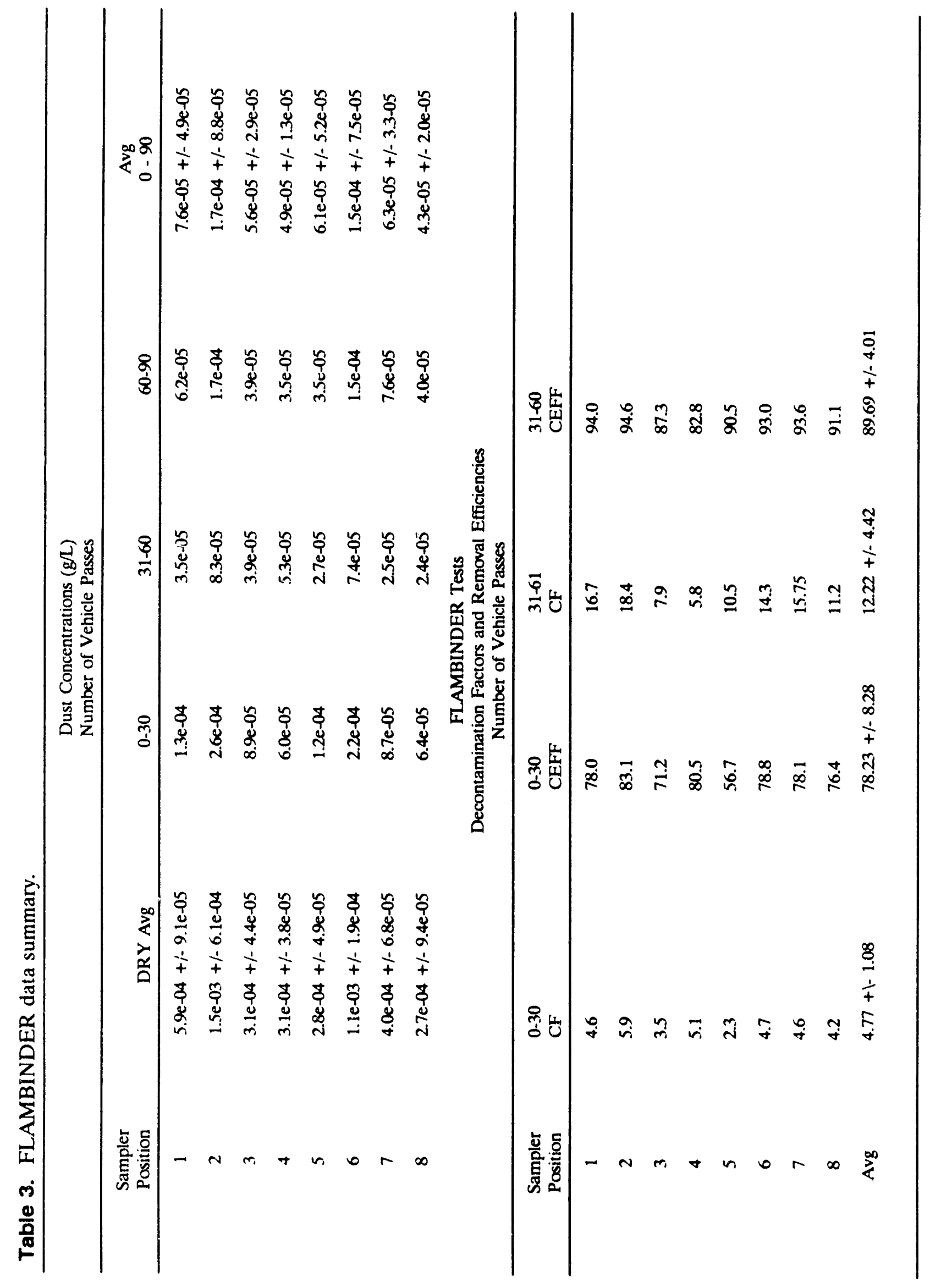




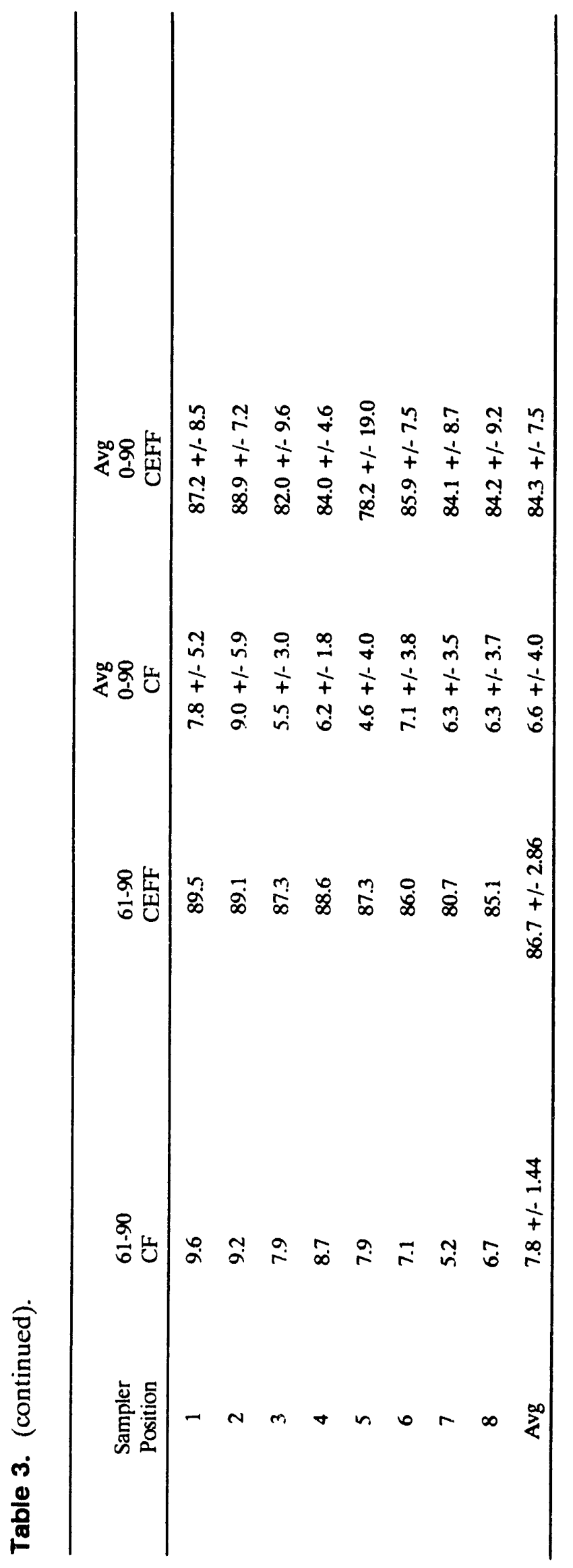




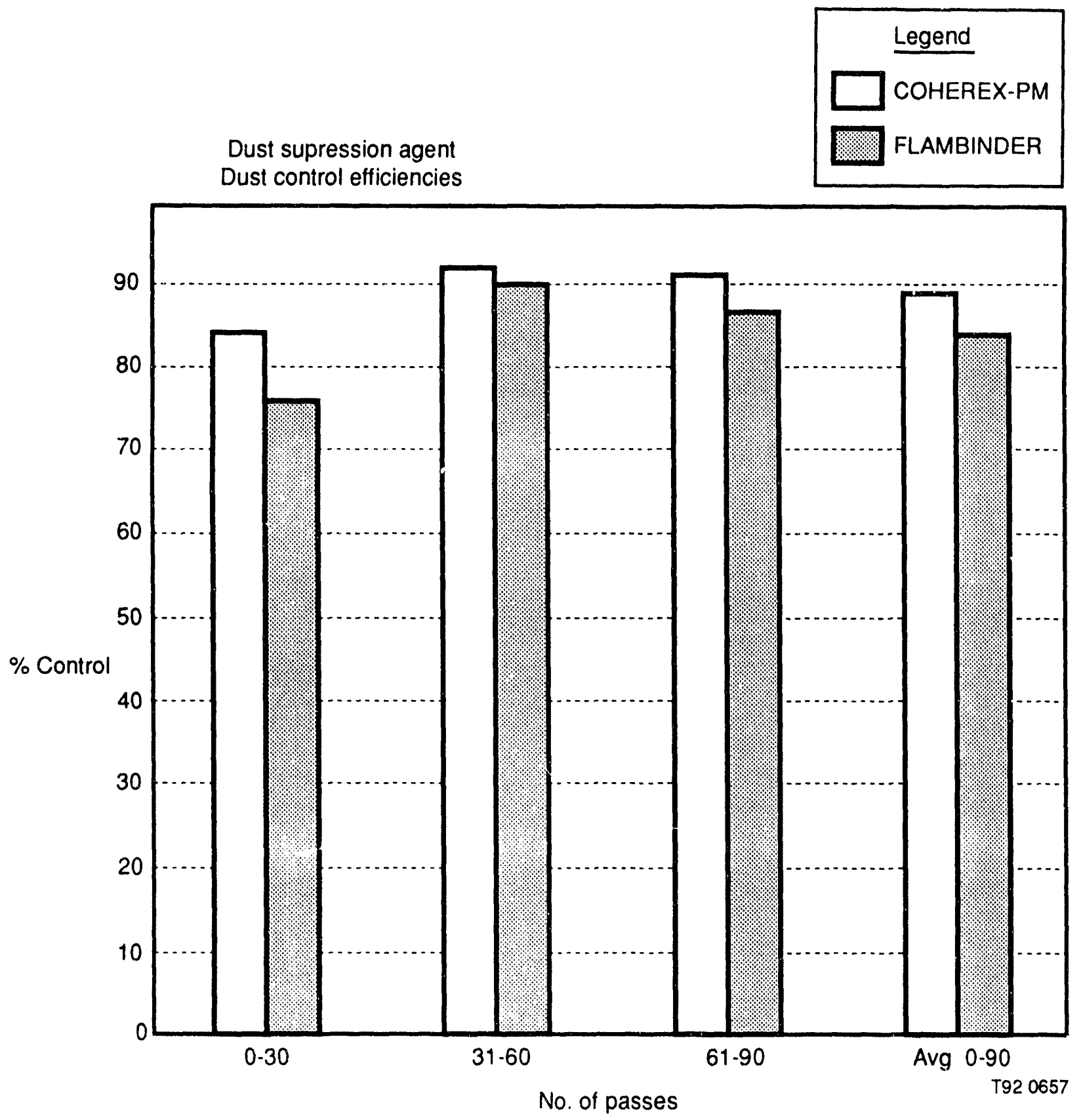

Figure 6. Comparison of soil fixative control efficiencies. 


\section{DISCUSSION AND RECOMMENDATIONS}

Table 4 shows the comparisons of each product to the experimental objectives that were outlined in Section 2.1. Included in this table are the results from the FY 1990 study done on ENTAC for further comparison.

The comparison of the environmental aspects shows that FLAMBINDER (calcium lignosulfonate) is the more acceptable product. The Material Safety Data Sheet (MSDS) states that it is considered a nonregulated and nonhazardous as per EPA and Department of Transportation (DOT) guidelines. Small quantities of carbon dioxide, carbon monoxide, and sulfur dioxide may he emitted during thermal decomposition at temperatures over $200^{\circ} \mathrm{F}$. The safety equipment required to apply the product include; robber gloves, safety glasses or goggles, rubber boots, and an apron. COHEREX-PM has several possible en vironmental issues for application at the INEL. The product is a petroleum-based product that ray raise some environmentál questions at the National Environmental Policy Act approval stage to use this product in an actual application. The product is not regulated by EPA or DOT. Several state environmental regulatory agencies in California and Arizona have approved the use of COHEREX-PM on roads and traffic areas. COHEREX-PM has also been used at DOE sites such as Rocky Flats and Hanford as a contamination control agent

Table 4. Soil fixative product comparisons.

\begin{tabular}{|c|c|c|c|}
\hline Objective & COHEREX-PM & FLAMBINDER & ENTAC \\
\hline Environmental & $\begin{array}{l}\text { Petroleum } \\
\text { hydrocarbon in } \\
\text { water emulsion }\end{array}$ & $\begin{array}{l}\text { Natural occurring } \\
\text { organic resin } \\
\text { derived from } \\
\text { lumber milling } \\
\text { process }\end{array}$ & $\begin{array}{l}\text { Natural occurring } \\
\text { organic resin from } \\
\text { treesap from lumber } \\
\text { milling process }\end{array}$ \\
\hline Application & $\begin{array}{l}\text { Product is } \\
\text { received in } \\
\text { concentrated form } \\
\text { and mixed with } \\
\text { water. Mixed } \\
\text { product is applied } \\
\text { with any available } \\
\text { tank and spray } \\
\text { system }\end{array}$ & $\begin{array}{l}\text { Product is received } \\
\text { in concentrated } \\
\text { form and mixed } \\
\text { with water. Mixed } \\
\text { product is applied } \\
\text { with any available } \\
\text { tank and spray } \\
\text { system }\end{array}$ & $\begin{array}{l}\text { Product is received } \\
\text { in concentrated form } \\
\text { and mixed with } \\
\text { water. Mixed } \\
\text { product is applied } \\
\text { with any available } \\
\text { tank and spray } \\
\text { system. }\end{array}$ \\
\hline Cost $\left(\$ / y d^{2}\right)$ & $\$ 0.64$ & $\$ 0.84$ & $\$ 0.65$ \\
\hline Indoor cure time $\mathrm{a}^{\mathrm{a}}$ & $6 \mathrm{hr}$ & $6 \mathrm{hr}$ & $36-48 \mathrm{hr}$ \\
\hline Control Efficiency & $\begin{array}{l}89.1+105.9 \\
\text { (avg } 0-90 \text { passes) }\end{array}$ & $\begin{array}{l}84.3+/-7.5 \\
\text { (avg } 0-90 \text { passes) }\end{array}$ & $\begin{array}{l}87.0+/-11.0 \\
\text { (avg 0.90 passes) }\end{array}$ \\
\hline
\end{tabular}


during remediation activities. ${ }^{a}$ Documentation of these events is being forwarded to the author and will be available for viewing in the project file.

Both COHEREX-PM and FLAMBINDER performed better than ENTAC in ease of application and cure times. There were no problems with clogging the lines, pumps, and nozzles of the application system. The cure times for both of these products were considerably less than ENTAC. The indoor cure time of each product tested this year was similar. It is important to note that this cure time was based on summertime conditions with daytime temperatures over $80^{\circ} \mathrm{F}$ and low humidity. The cure time will vary at lower temperatures and higher humidity. The cure times for COHEREX-PM and FLAMBINDER should be acceptable in a indoor retrieval or waste handling operation.

All of the products may be diluted with water in an application tank such as the one planned for the field deployable contamination control unit (FDCCU). The product can then be applied using a pump hose and nozzle from the mixing tank to the desired area. All of these components are readily available and easily assembled.

Application costs for each product show that COHEREX-PM is the more economical product to apply. However, the difference in application costs may not be enough to offset the environmental applicability problems that COHEREX-PM may face when compared to FLAMBINDER.

As with most chemical products both FLAMBINDER and COHEREX-PM have similar competitive products marketed by other vendors. For example, Chemlink Industries, of Houston, Texas, markets a calcium lignosufonate product called DUSBLOC-310 and Syntech Corporation of Toledo, Ohio, markets a petroleum emulsion product called PETROTAC. Based on the examination of the MSDS for each of these products, there are little differences between these products and the products tested.

The $\mathrm{C}_{\text {eff }}$ of each product was statistically the same within the standard deviations of the measurements made of each products performance. All products meet the desired degree of control as outlined in the test objectives.

In conclusion, it was determined that both COHEREX-PM and FLAMBINDER meet the requirements to control fugitive dust generation on vehicle traffic surfaces during waste retrieval and handling operations that could occur at the RWMC provided COHEREXPM can be found environmentally acceptable. Both products are suitable for use in the FDCCU to be constructed during FY 1993.

a. Private communication with Roy McNeil, Witco Corporation, Chandler, Arizona, May 13, 1992. 


\section{REFERENCES}

1. M. R. Winberg, R. J. Pawelko, N. C. Jacobs, D. N. Thompson, Engineering Scale Dust Control Experiments, EGG-WTD-9387, December 1990.

2. S. W. Duce, M. R. Winberg, A. L. Freeman, Basic Radiological Studies Contamination Control Experiments, EGG-WM-8724, September 1989.

3. M. R. Winberg, Test Plan for FY-91 Dust Control Studies, EGG-WTD-9553, March 1991.

4. EG\&G Idaho, Standard Practices Manual.

5. G. G. Loomis, D. E. Menkhaus, D. W. Scott, "A System to Control Contamination During Retrieval of Buried TRU Waste", Waste Management 90, Tucson Arizona, February 25 March 2, 1990. 


\section{Appendix A}

Calculational Methods 
.

A-2 


\section{Appendix A}

\section{Calculational Methods}

All initial data used to make the calculations to determine the results contained in this report is found in Appendix $A$ of this report. For each test sequence a dust control factor (CF) and dust control efficiency $\left(\mathrm{C}_{\text {eff }}\right)$ was calculated, where

$\mathrm{CF}=\mathrm{C}_{\mathrm{n}} / \mathrm{C}_{\mathrm{v}}$

$C_{\text {eff }}=1-\left[C_{v} / C_{n}\right] * 100$

where

$C_{n}=$ The average dust concentration at a particular sampler location in $g / L$ with no soil fixative applied

$\mathrm{C}_{\mathrm{v}}=$ The average dust concentration at a particular sampler location in $\mathrm{g} / \mathrm{L}$ for all test sequences with the soil fixative applied.

All averages and standard deviations for each sampler location were calculated by using the following equations:

$A V G=\left(\Sigma C_{i}\right) / N$

Note: this value was used as $C_{n}$ or $C_{v}$ depending on the test sequence.

$\mathrm{STD}=\operatorname{SQRT}\left[\Sigma\left(\mathrm{C}_{\mathrm{i}}-\mathrm{AVG}\right)^{\wedge} 2 /(\mathrm{N}-1)\right]$

where

$C_{i}=$ The concentration in $g / L$ for each sample location for each test sequence performed

$\mathrm{N}=$ The number of times each test was run.

The standard deviation for the control factor and control efficiency is calculated as

$\operatorname{STD}_{\mathrm{CF}}=\mathrm{CF} * \operatorname{SQRT}\left[\left(\sigma_{\mathrm{C}} / \mathrm{c}_{\mathrm{n}}\right)^{2}+\left(\sigma / \mathrm{C}_{\mathrm{V}}\right)^{2}\right]$

$\operatorname{STD}_{\text {Ceff }}=\left(100-\mathrm{C}_{\text {eff }} * \operatorname{SQRT}\left[\sigma_{\mathrm{Cn}} / \mathrm{C}_{\mathrm{n}}\right)^{2}+\left(\sigma_{\mathrm{Cv}} / \mathrm{C}_{\mathrm{v}}\right)^{2}\right]$

where

$\sigma_{\mathrm{Cn}}=$ The standard deviation of the average dust concentration at a particular sampling location with no soil fixative applied. 
$\sigma_{\mathrm{Cv}}=$ The standard deviation of the average dust concentration at a particular sampling location with the soil fixative applied. 


\section{,}
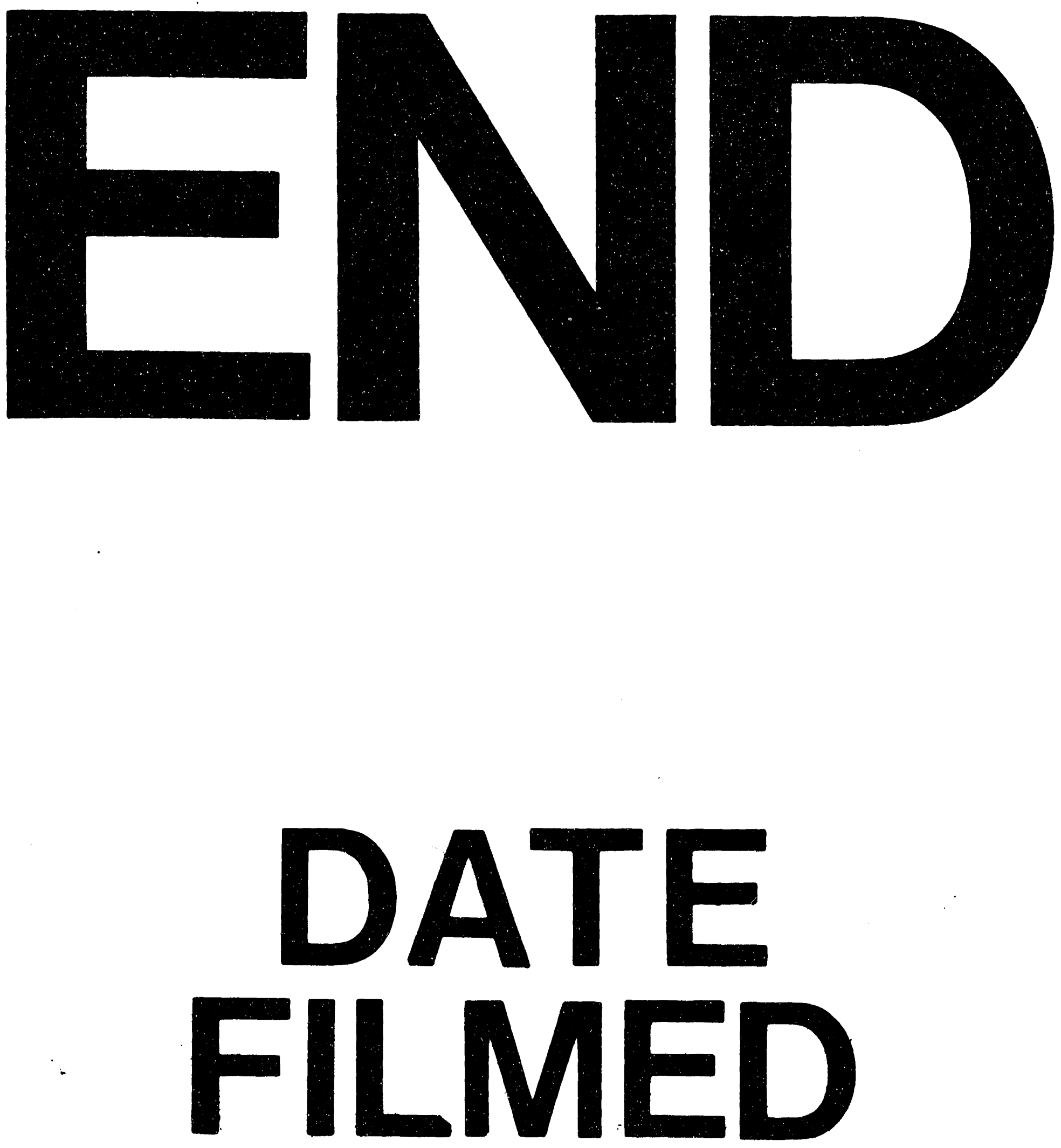

1

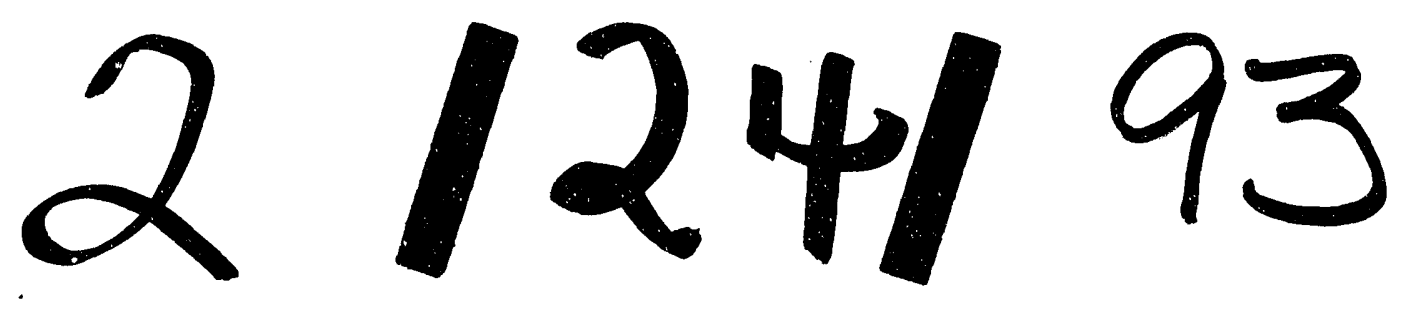


